\title{
Evaluation of the location of cities in terms of land cover on the example of Poland
}

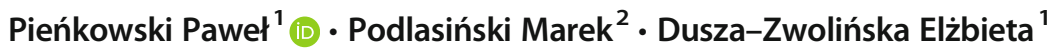

Published online: 28 March 2019

(C) The Author(s) 2019

\begin{abstract}
The increasing availability of remote sensing materials of varying spatial resolution inclines to look for methods enabling their use, both at planning the spatial structure of particular urban centers and shaping the global urban development policy on the national level. Urban development valorization should include the evaluation of urban greening while taking into account the surrounding landscape. Therefore, this work aimed at developing a method which would consider those two elements. By using the proposed method, all cities of Poland within their administrative boundaries were classified into generalized types. They are characterized by cities' location in relation to the dominant landscape background which can be helpful in planning the actions in relation to developing the urban greening, as well as evaluating of the quality of life of the residents at the national level. Due to the landscape element, the decline in the quality of life of residents may concern a large group of cities located within the anthropogenic and agricultural landscape as well as the urban and agricultural, where the harmful effects of pollution from residential energy, industry, and farming often overlap. The method presented in this work can be used in relation to cities in other countries or to larger areas, enabling comparison between them.
\end{abstract}

Keywords Urban greening · Lands cover · Cities in ecology · Quality of life · Geographic information system

\section{Introduction}

Associating the urban areas with the surrounding landscape is one ofthe elements which should be taken into consideration while valorizing the cities in terms of quality of life of their residents (Hobbs 1997; Kuo 2003; Arnberger 2006; Matsuoka and Kaplan 2008). This approach is incorporated into the concept of shaping the city's spatial policy, referred to as "the city in ecology," (Naess 2001; Hulicka 2015) where the city is part of a larger ecosystem and where the relationship between the city and its surroundings should be taken into account when planning spatial development.

Pieńkowski Paweł

ppienkowski@zut.edu.pl

1 Department of Ecology, Environmental Protection and Management, West Pomeranian University of Technology in Szczecin, al. Piastów 17, 70-310 Szczecin, Poland

2 Department of Soil Science, West Pomeranian University of Technology in Szczecin, al. Piastów 17, 70-310 Szczecin, Poland
Sustainable urban development concepts should therefore take into account not only the increase in natural diversity, the development of urban green areas, the structure of the use of land forms (Bjerke et al. 2006; Ahern et al. 2014; Mierzejewska 2015) and landscape values (Myga-Piątek 2010; Basten 2011), but also consider the impact of the way of use of suburban areas which affect the air quality and health of cities residents (Miller and Hobbs 2002; Wolch et al. 2014).

Planning sustainable development of urban centers should include areas outside of their borders, also because of their environmental, climatic ( $\mathrm{Li}$ et al. 2005; Escobedo et al. 2011), and recreational role (Stigell and Schantz 2015; Mierzejewska 2015a). This tendency includes the so-called concept of green infrastructure, based on the idea of joining parks and other green areas through the system of corridors (Collinge 1998; Hidding and Teunissen 2002). Its aim is to improve the quality of life of urban citizens, protect landscape, and preserve biodiversity, as well as to prevent excessive greenery path insulation (Collinge 1996; Benedict and McMahon 2002; Bruszewska 2013). Additionally, when planning the proper system of urban greening, European Environment Agency (2011) recommends including areas outside of the administrative 
boundaries of cities. The first stage of action should include the analysis of the diversity of green areas within the city borders and their nearest peripheries. The next step should include such elements as; forest parks, lakes, rivers, agricultural areas, urban forests, and should consider the connection of a city to the surrounding landscape.

What should be sought are external connections that can fulfill essential ecological functions such as natural migration corridors and ecological islands (Ahern et al. 2014). It is particularly important in times of strong urbanization of suburban areas (Antrop and Van Eetvelde 2000; Antrop 2004; Xiao et al. 2006) as well as the increasing devastation of the landscape within these areas (Drapella-Hermansdorfer 2005; Żarska 2005; Troy et al. 2007). Therefore, the protection of suburban areas should be an integral part of the comprehensively understood problems of urban protection and should be carried out on a broader scale of landscapes (Żarska 2005; Solon et al. 2015).

The problem of the impact of land use on the health of residents is of increasing public concern. Especially, in the face of emerging numerous works documenting the growth of mortality rates due to pollutants coming from the areas used for agriculture (Lelieveld et al. 2015). Paradoxically, small towns located within the boundaries of agricultural landscapes can be subject to various air pollutants from farming (Pope and Dockery 2006; Balarasa et al. 2007; Beelen 2014; Lelieveld et al. 2015). These reports confirm the necessity of searching for new methods of determining relations of urban areas with the landscape surrounding the city (Vuilleumier and Prelaz-Droux 2002).

The availability of remote sensing materials facilitates analysis of this type, especially in relation to selected cities (Feranec et al. 2000; Zhang et al. 2004; Balrama and Dragicević 2005; Xiao et al. 2006; Feranec et al. 2007; Kong et al. 2007; Bagan and Yamagata 2012). However, when assessing a large and size-differentiated group of cities, for example, on the national level, a number of difficulties can be encountered. These difficulties relate to data generalization and the necessity for systematizing relations between a city and its surroundings (Runge 2012). The use of the method determining the dominant landscape background seems to be helpful in achieving this aim (Pieńkowski and Podlasiński 2017). This method helps to generalize the land cover type within the city along with neighboring areas. In addition, it facilitates choosing the connections which condition important ecological functions, including the existence of ecological corridors and islands. This is particularly important in times of strong urbanization of suburban areas neighboring with large cities (Cook 2002; Opdam et al. 2006; Bryant 2006; Mierzejewska 2015; Drapella-Hermansdorfer 2005; Nowak et al. 2010). Applying this method also allows determining the location of cities in terms of the landscape and dividing them which is presented in this work.
Fig. 1 Stages determine the areas defining the dominant land use (> 50\%) for example surroundings of Szczecin city. a - distribution the type of land use (part of the map Corine Land Cover 2006), b - "A" map after filtration ( $2 \mathrm{~km}$ radius), $\mathbf{c}-$ "A" map with overlaid areas illustrating the limits of the dominant land use (> 50\%). Fo - forest landscape, Ar agricultural landscape, $\mathrm{Wa}$ - water and wetland landscape, Ur - urban landscape

\section{Material and method of landscape background determination}

Data on the location and surface of the cities were gathered based on publicly available spatial Corine Land Cover (Hościło and Tomaszewska 2014) and statistical data (GUS 2016). The Corine Land Cover database was used, from which four types of land covers were identified: agricultural areas, urban areas, forests, and waters with wetlands. Green urban areas and sport and leisure facilities, which are part of Corine Land Cover's artificial surfaces level, have been included to the forest areas.

In this work, maps of Polish landscape backgrounds were used based on the calculations carried out according to the Pieńkowski and Podlasiński methodology (Pieńkowski and Podlasiński 2017). For the generalization of land cover forms, a method based on spatial moving average (moving windows) was used, the modification of which was applied in this paper ("Resampling Filter" module in the SAGA GIS program). It is assumed that the dominance of a given type of use is determined by the value of the raster attribute. It is obtained on the basis of the use of filtration module, and it falls within the range of 0 to $100 \%$, where a zero value means no impact of a given landscape category, and a $100 \%$ value means total land cover for this category. The areas where the attribute value is over $50 \%$ were considered the dominant landscape background.

A filtration process was carried out for all four selected forms of land cover (Fig. 1b). Then, for each of them, areas for which the raster attributes are above $50 \%$ were set (Fig. 1c). Zones of dominant landscape background were created by overlaying these areas (Fig. 2). For each of four search radii used in the work $(0.5,1.0,2.0,4.0 \mathrm{~km})$ a map was obtained of the dominant land cover (hereinafter referred to as the landscape background). The dominance of a given form of use ( $>50 \%)$ at a given radius was taken into account - as well as areas where none of the forms of use accounted for more than 50\% (mixed use). When choosing the search radius, it was suggested to use, i.a. an average diameter of national cities, which in Poland is $2 \mathrm{~km}$; an average walking distance, estimated at 2.5-3 km (Stigell and Schantz 2015); as well as the distance of pollution effect coming from agricultural sources (Asmann et al. 1998, Sutton et al. 2003). Some authors in the analysis of the influence of the landscape on the city take into account the area surrounding it, using a specified buffer size (Bagan and Yamagata 2012). However, the use of landscape background and the accepted 

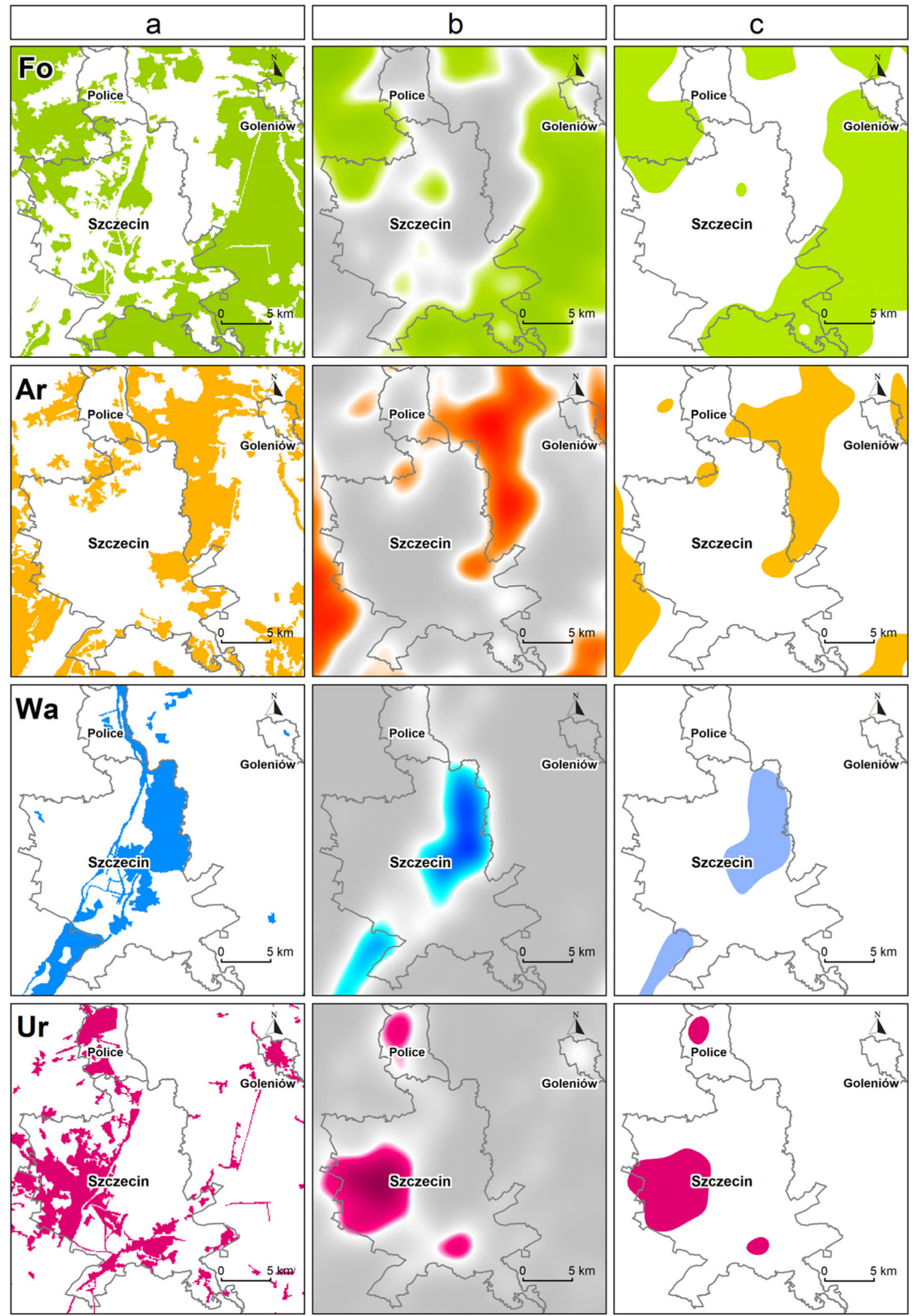

degree of blurring (search radius) facilitates generalization degree of the data and allows for the simultaneous capturing of interaction between different ways of land cover within the city boundaries and beyond them. 
Fig. 2 Zones of landscape background for example surroundings of Szczecin City at different search radius (SR). 1 forest landscape, 2 -agricultural landscape, 3 - water and wetland landscape, 4 - urban landscape, 5 - mixed landscape
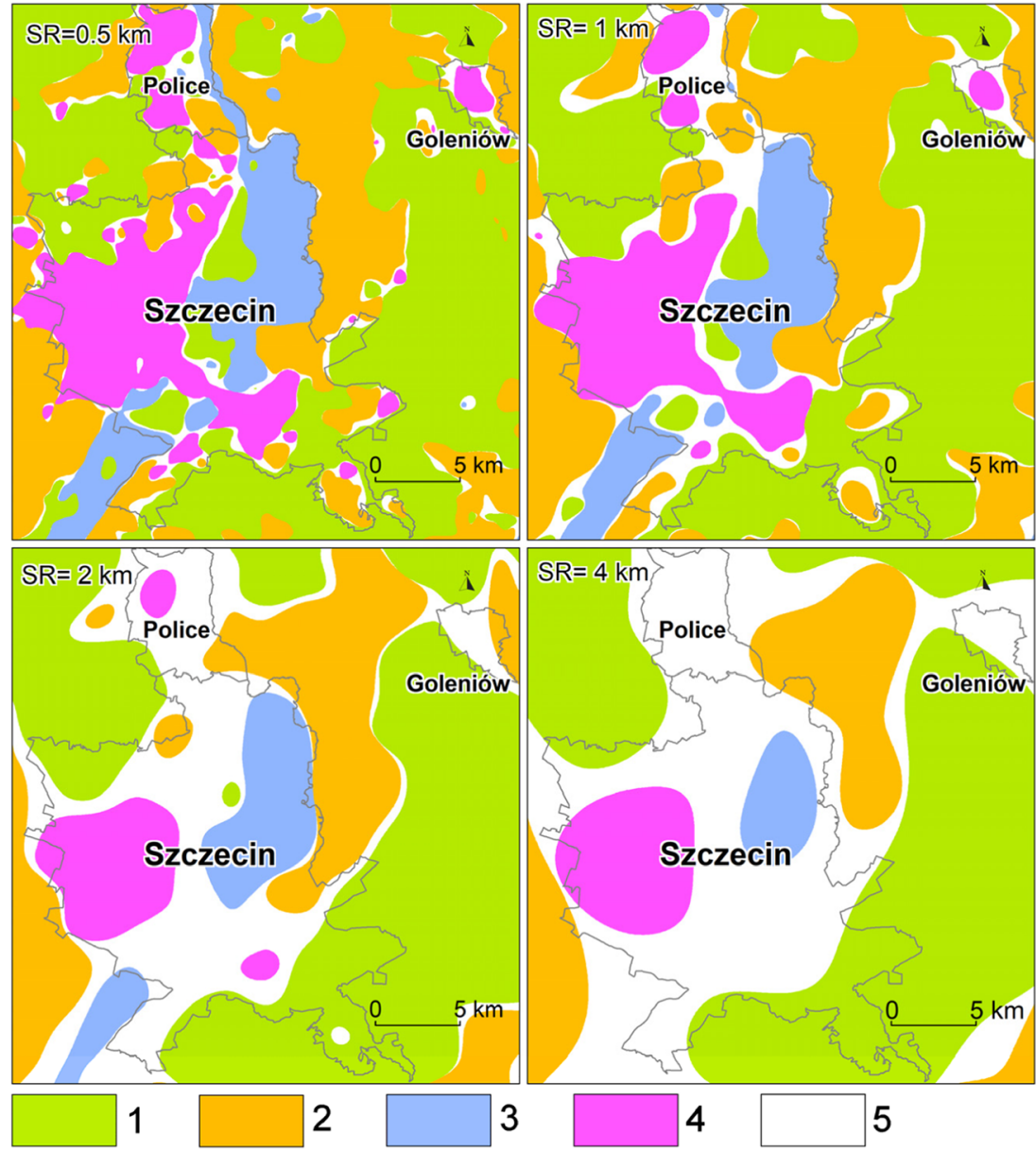

3

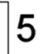

All cities of Poland are classified according to their location in terms of the landscape background. Four groups were distinguished from among 928 Polish cities, depending on the landscape background (forest, agricultural, urban, water
Fig. 3 Examples of the cities' location in terms of landscape background (search radius $2 \mathrm{~km}$ ): a agricultural, $\mathbf{b}$ forest, $\mathbf{c}$ water and wetland, $\mathbf{d}$ urban, e mixed landscape
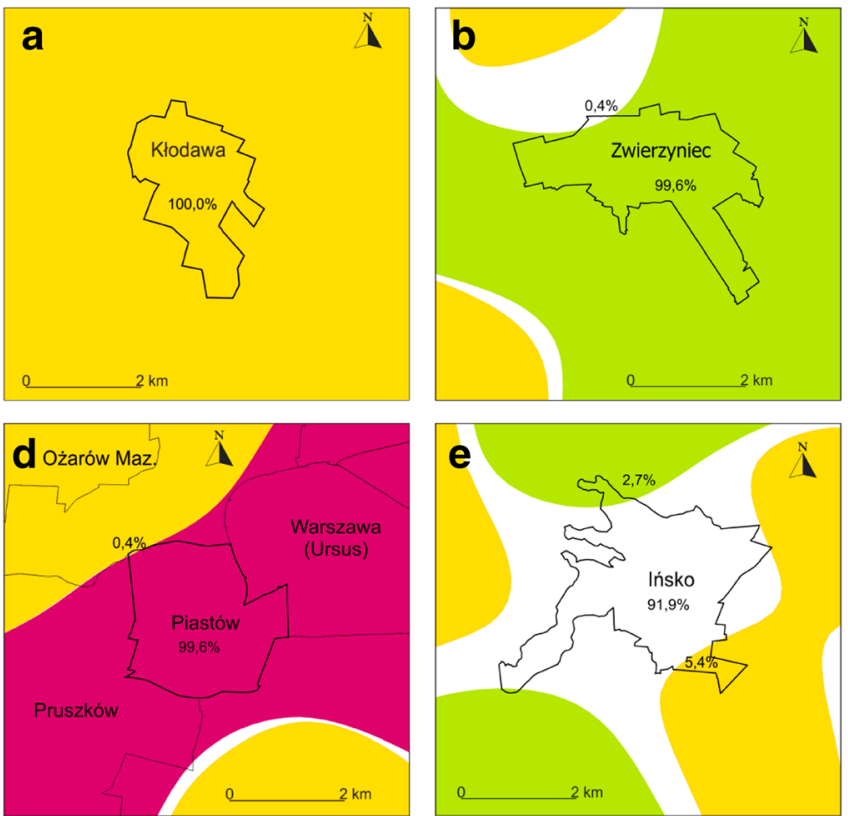

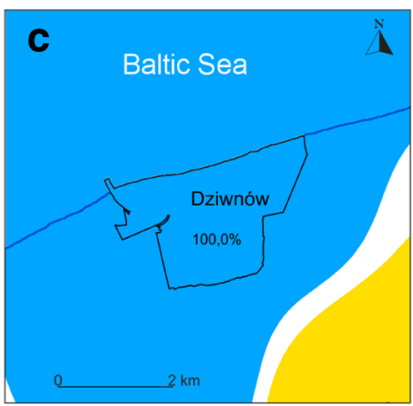


Fig. 4 Examples of the differentiated location of cities in Poland in terms of the landscape background with their graphics presentation including four ranges of search radius (SR rings: 0.5, $1.0,2.0,4.0 \mathrm{~km})$; within the administrative boundaries of the city (a) and boundaries of dense urban buildings (b). Color explanations see Fig. 3

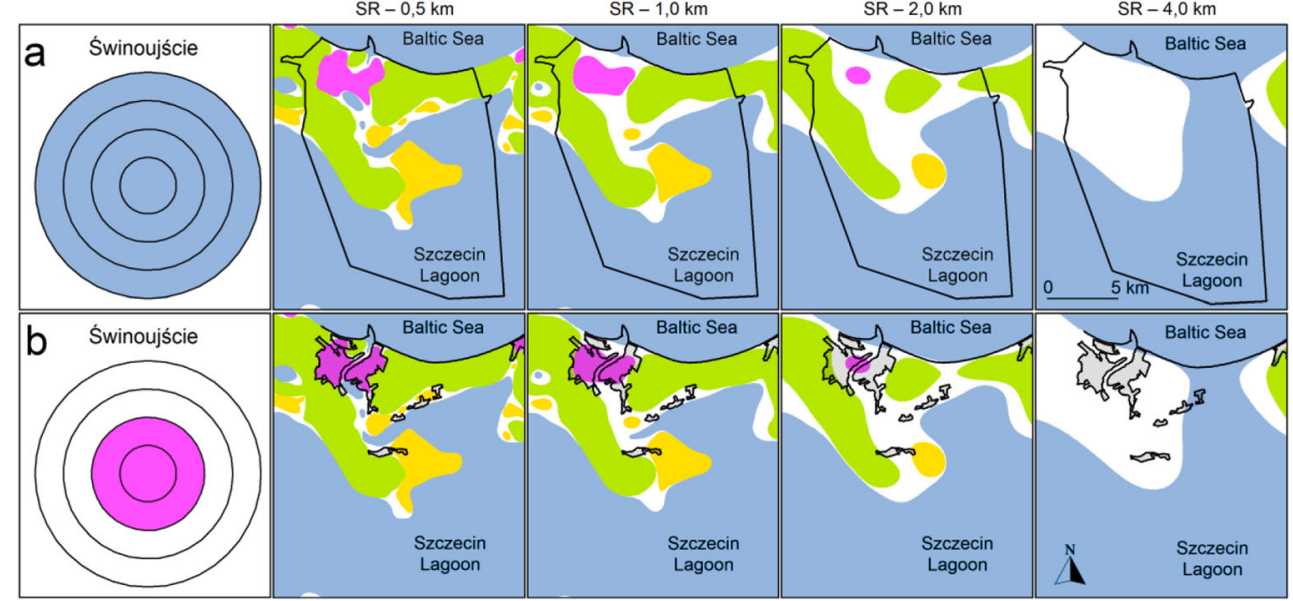

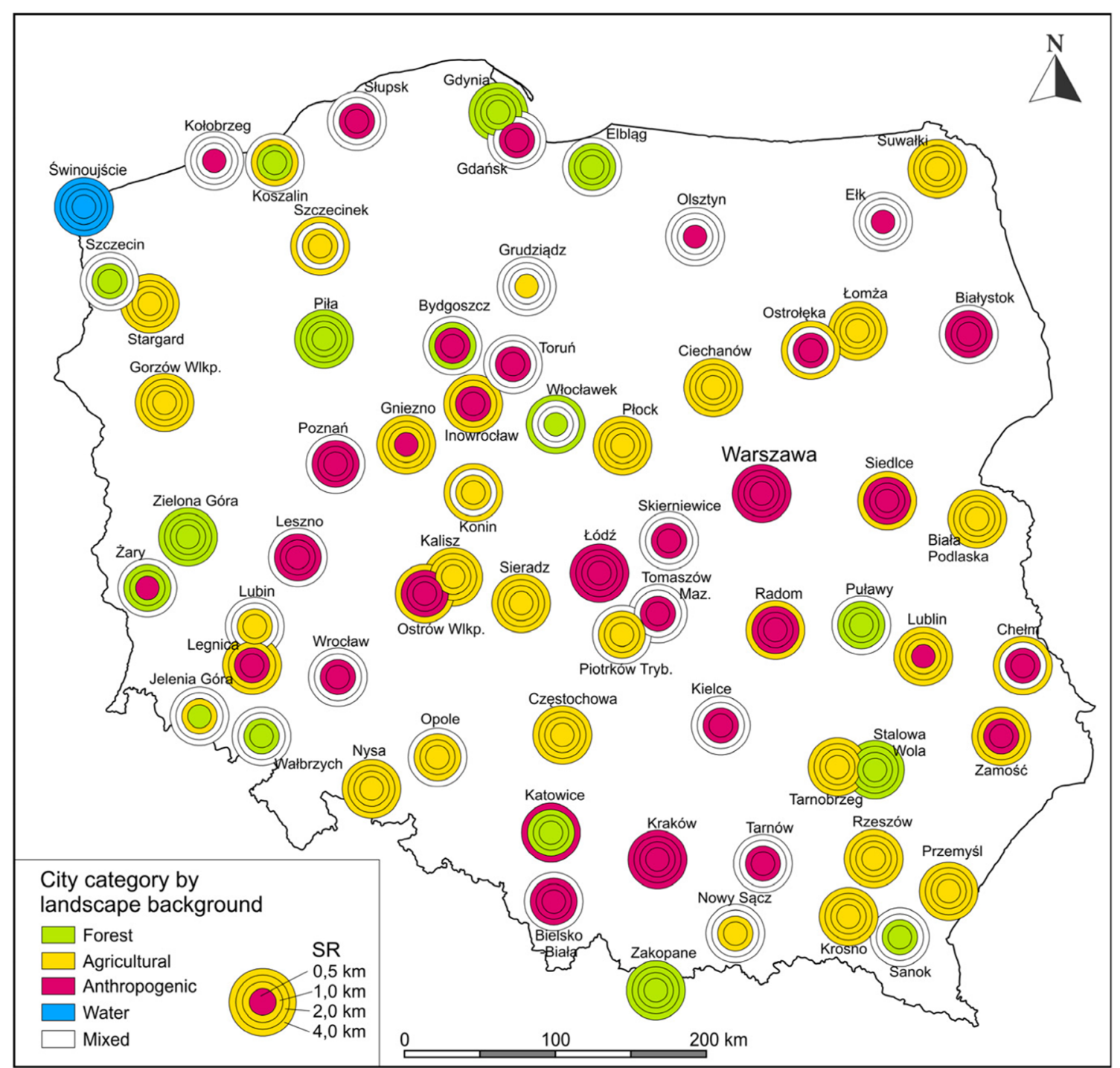

Fig. 5 Example of graphical presentation of heterogeneous landscape background of selected cities in Poland ( $>40$ thousand residents) designated within their administrative boundaries 


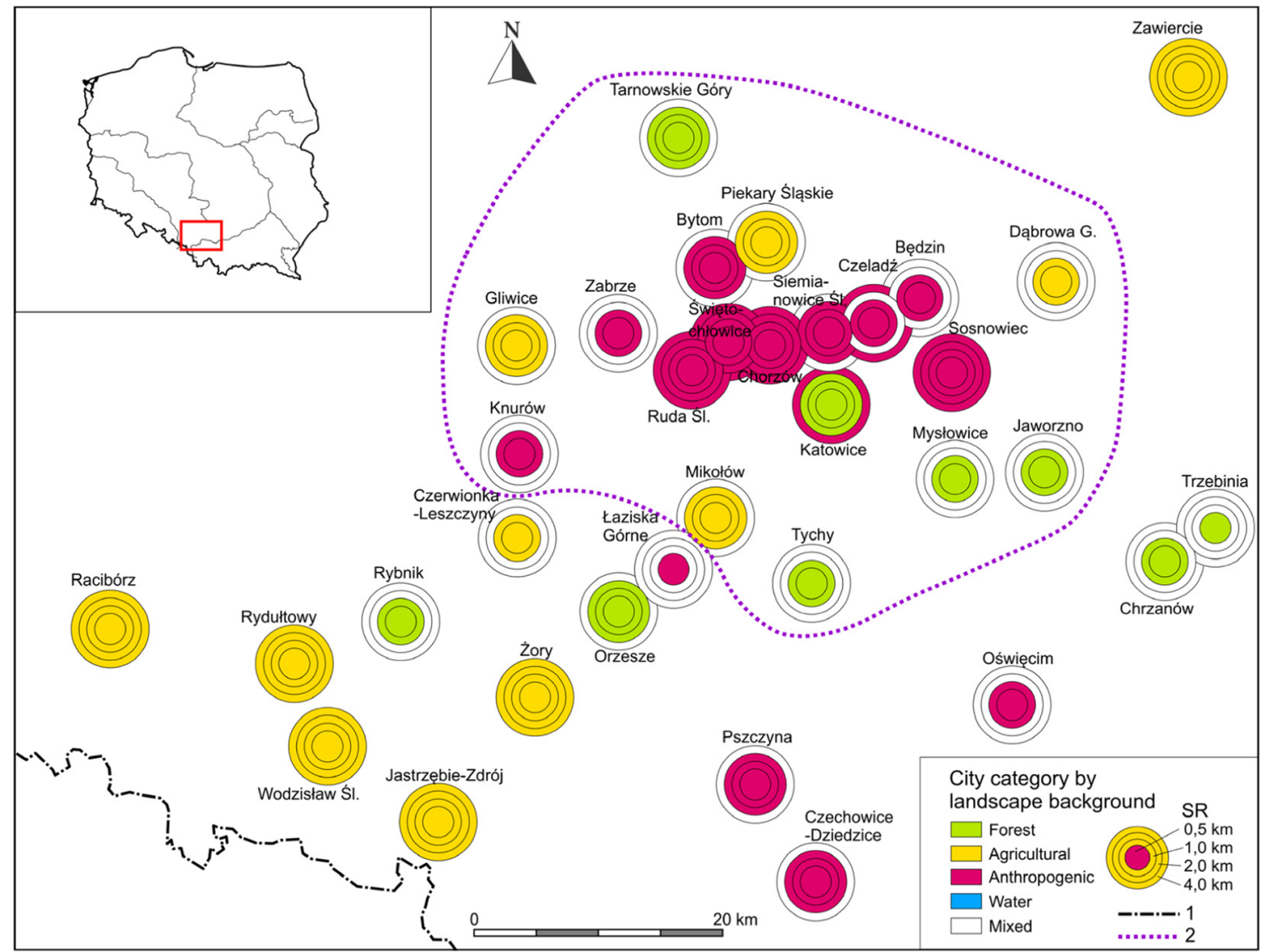

Fig. 6 Example of graphical presentation of the heterogeneous landscape background of the cities of Upper Silesia, designated within the administrative boundaries of 1 - state boundaries, 2 - the Upper Silesia boundaries

and wetlands). Also, an additional group with a predominantly mixed background was distinguished (where there are at least three types of coating with a similar degree of coverage). Examples of the cities located in the background of the dominant land cover are presented in Fig. 3.

When classifying the cities into population, a simplified distinction according to Szymańska (2007) was used. When it comes to cities, they were divided into five groups based on their surface $\left(<10,10-20,20-50,50-100,>100 \mathrm{~km}^{2}\right)$.

Due to the fact that within the administrative boundaries of cities in Poland, undeveloped areas (such as urban forests, parks, lakes or fields) may have a significant share, the determination of the location of the city in terms of the landscape background was made both with respect to administrative boundaries and to the built-up areas, in which the majority of the city's inhabitants live.

Given that landscape background presented in the work depends on the radius search, its four dimensions were selected. They can approximately correspond to the range of direct impact of land use on the quality of life of urban residents, presented in the literature. Examples of the differentiated location of cities in Poland in relation to the background in selected radius searches $(0.5,1.0,2.0,4.0 \mathrm{~km})$ with their graphic presentation are shown in Fig. 4. Other rings of circles show the dominant land cover (landscape background) in range of four search radii. Moreover, the figure explains the problem resulting from the fact that within the administrative boundaries of cities significant areas prevail there: urban forests, surface waters, and even arable land. Not taking these elements into account would often lead to oversimplification of the inference, especially regarding quality of life of residents in large urban centers. To avoid this, applied were two ways of evaluating the city's position in terms of the landscape background. The first one includes the qualification of the city carried out within its administrative boundaries. The second one (used in the subchapter The heterogeneity of the city landscape background within built-up areas) includes only the area of dense urban areas. The need to do so relates particularly to larger cities. In relation to smaller cities $(<20$ thousand residents), the dominant landscape background of surrounding areas so strongly affects the area of the city that some of forest and water areas within the city are of little value at its qualification to a dominant landscape background.

Świnoujście is an example of a city illustrating the need of such approach. This is linked with the fact that within the administrative boundaries of Świnoujście, there are large areas 
Table 1 The number of Polish cities in given landscape types

\begin{tabular}{|c|c|c|c|c|c|c|c|c|}
\hline \multirow[t]{3}{*}{ Type } & \multirow[t]{3}{*}{ Subtype } & \multirow[t]{3}{*}{ Class } & \multicolumn{6}{|c|}{ Number of cities } \\
\hline & & & \multicolumn{6}{|c|}{ Size ranges $\left[\mathrm{km}^{2}\right]$} \\
\hline & & & $<10$ & $10-20$ & $20-50$ & $50-100$ & $>100$ & Total \\
\hline & & & \multicolumn{6}{|c|}{ Urban landscape } \\
\hline \multirow[t]{10}{*}{$\mathrm{U}$} & U4 & U4 & 1 & 5 & 2 & 4 & 6 & 18 \\
\hline & & U3/a1 & 0 & 5 & 6 & 0 & 2 & 13 \\
\hline & $\mathrm{U} / \mathrm{a}$ & $\mathrm{U} 2 / \mathrm{a} 2$ & 15 & 18 & 9 & 1 & 0 & 43 \\
\hline & & $\mathrm{U} 1 / \mathrm{a} 3$ & 25 & 11 & 6 & 1 & 2 & 45 \\
\hline & & $\mathrm{U} 3 / \mathrm{m} 1$ & 2 & 4 & 7 & 1 & 4 & 18 \\
\hline & $\mathrm{U} / \mathrm{m}$ & $\mathrm{U} 2 / \mathrm{m} 2$ & 6 & 18 & 18 & 1 & 2 & 45 \\
\hline & & $\mathrm{U} 1 / \mathrm{m} 3$ & 4 & 4 & 4 & 1 & 0 & 13 \\
\hline & & $\mathrm{U} 3 / \mathrm{f1}$ & 0 & 0 & 0 & 0 & 0 & 0 \\
\hline & $\mathrm{U} / \mathrm{f}$ & $\mathrm{U} 2 / \mathrm{f} 2$ & 2 & 1 & 0 & 0 & 0 & 3 \\
\hline & & $\mathrm{U} 1 / \mathrm{f3}$ & 3 & 0 & 1 & 1 & 0 & 5 \\
\hline & & & \multicolumn{6}{|c|}{ Agricultural landscape } \\
\hline \multirow[t]{8}{*}{ A } & A4 & A4 & 229 & 163 & 99 & 17 & 1 & 509 \\
\hline & $\mathrm{A} / \mathrm{m}$ & $\mathrm{A} 3 / \mathrm{m} 1$ & 8 & 5 & 6 & 2 & 1 & 22 \\
\hline & & $\mathrm{A} 2 / \mathrm{m} 2$ & 0 & 6 & 4 & 0 & 1 & 11 \\
\hline & & $\mathrm{A} 1 / \mathrm{m} 3$ & 5 & 1 & 1 & 0 & 0 & 7 \\
\hline & & $\mathrm{A} 3 / \mathrm{f} 1$ & 4 & 3 & 1 & 0 & 0 & 8 \\
\hline & $\mathrm{A} / \mathrm{f}$ & $\mathrm{A} 2 / \mathrm{f} 2$ & 5 & 2 & 1 & 0 & 0 & 7 \\
\hline & & $\mathrm{A} 1 / \mathrm{f3}$ & 2 & 2 & 0 & 1 & 0 & 5 \\
\hline & & & \multicolumn{6}{|c|}{ Forest landscape } \\
\hline \multirow[t]{10}{*}{$\mathrm{F}$} & F4 & $\mathrm{F} 4$ & 7 & 19 & 28 & 18 & 4 & 76 \\
\hline & & $\mathrm{F} 3 / \mathrm{m} 1$ & 2 & 1 & 2 & 5 & 0 & 10 \\
\hline & $\mathrm{F} / \mathrm{m}$ & $\mathrm{F} 2 / \mathrm{m} 2$ & 2 & 5 & 8 & 1 & 1 & 17 \\
\hline & & $\mathrm{F} 1 / \mathrm{m} 3$ & 0 & 3 & 1 & 0 & 1 & 5 \\
\hline & $\mathrm{F} / \mathrm{a}$ & F3/a1 & 3 & 2 & 5 & 1 & 0 & 11 \\
\hline & & $\mathrm{F} 2 / \mathrm{a} 2$ & 2 & 3 & 0 & 1 & 0 & 6 \\
\hline & & $\mathrm{F} 1 / \mathrm{a} 3$ & 2 & 1 & 0 & 0 & 0 & 3 \\
\hline & $\mathrm{F} / \mathrm{w}$ & $\mathrm{F} 2 / \mathrm{w} 2$ & 0 & 1 & 1 & 0 & 0 & 2 \\
\hline & $\mathrm{F} / \mathrm{u}$ & F3/u1 & 0 & 0 & 0 & 0 & 1 & 1 \\
\hline & & & \multicolumn{6}{|c|}{ Water and wetland landscape } \\
\hline \multirow[t]{6}{*}{ W } & W4 & W4 & 2 & 0 & 1 & 0 & 2 & 5 \\
\hline & $\mathrm{W} / \mathrm{a}$ & W3/a1 & 0 & 1 & 0 & 0 & 0 & 1 \\
\hline & & $\mathrm{W} 2 / \mathrm{a} 2$ & 2 & 1 & 1 & 0 & 0 & 4 \\
\hline & $\mathrm{W} / \mathrm{m}$ & $\mathrm{W} 2 / \mathrm{m} 2$ & 0 & 1 & 0 & 0 & 0 & 1 \\
\hline & & $\mathrm{W} 1 / \mathrm{m} 3$ & 1 & 0 & 0 & 0 & 0 & 1 \\
\hline & & & \multicolumn{6}{|c|}{ Mixed landscape } \\
\hline M & $\mathrm{M} / \mathrm{x}$ & & 11 & 0 & 1 & 0 & 0 & 12 \\
\hline Total & & & 345 & 286 & 213 & 56 & 28 & 928 \\
\hline
\end{tabular}

of waters along with numerous small islands and forests (altogether, their area constitutes $72.8 \%$ of the city's area), while the built-up area occupies only $10 \%$ of its area. While qualifying the location of the city in terms of the dominant landscape, which takes into account the course of its administrative boundaries; the city, regardless of the search radius, is located in a water and wetlands landscape (Fig. 4a). When only taking into account the built-up area, in the first two radii, the dominant is an anthropogenic landscape (Fig. 4b). However, the presented example of a city is an outlier as in most analyzed cities the differences resulting from two different methods of calculation are not so clear.

To summarize the aforementioned problem, the first of presented methods informs within which dominant landscape the entire area of the city is located (taking into account its administrative boundaries). The second method informs us within which landscape the dense urban buildings area is located. It seems that for the general division of the cities in terms of the surrounding landscape background it is more appropriate to operate with the administrative boundaries (which has been applied in this work), while for the attempt to determine the direct impact of the landscape on the quality of resident's life, it is appropriate to narrow the analysis to built-up areas.

\section{Application of the method in the classification of Polish cities}

Using the criteria presented in this methodology, the cities are located within the differentiated background, which largely reflects the agro-forest nature of the country. Poland is dominated by agricultural land, which constitutes $59.8 \%$ of the country's surface, and then, by forests, which constitute $32.7 \%$.

The differentiation of location of chosen cities in terms of landscape background regarding administrative boundaries is presented in Figs. 5 and 6. The first one shows the diversity of the landscape background of the selected Polish cities with more than thousand residents. The second one takes into account the densely populated area of Upper Silesia, including Katowice urban area, which is characterized by a large variety in terms of industrialization and the nature of land use.

Keeping in mind the interaction between urban areas and the surrounding areas, all Polish cities were divided within their administrative boundaries because of their dominant landscape background. It includes the structure of the land cover within the city area as well as the area outside its boundaries. The distinguished types include five types of landscape (including the mixed landscape), four search radii, and their organized combinations. The number in a given type, subtype, and class, depending on the size of the city is shown in Table 1. Type of the city was determined by the dominant landscape within the administrative boundaries, calculated with the smallest search radius $(0.5 \mathrm{~km})$. Including this radius, $22 \%$ of Polish cities were accounted for in the urbanized type (U). Cities of the agricultural type (A) constitute the largest group $(61 \%)$, which relates to the dominant share of agricultural land within the country's landscape. Cities of the forest 
Fig. 7 Example of determining types of cities with dominant anthropogenic land cover depending on adopted search radius. Color explanations see Fig. $1, \mathrm{SR}-$ search radius
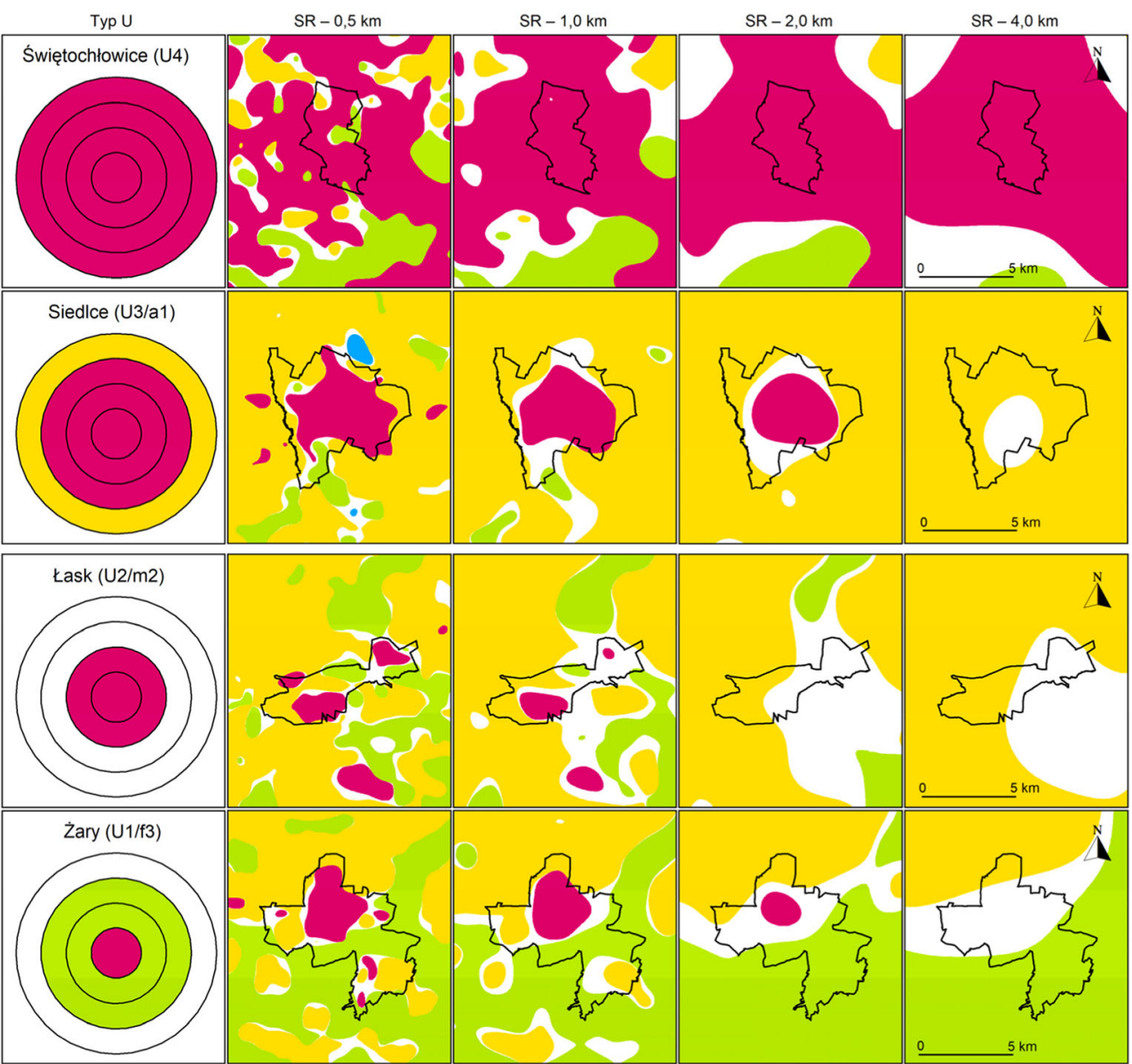

type $(\mathrm{F})$ constitute a much smaller amount $(14 \%)$ than the share of the whole country's use would indicate. The remaining $3 \%$ are cities of the water (W) and mixed type (M).

The use of larger radius qualified the city for the subtypes and classes (Fig. 7). The first of presented groups are the cities of the urban type (U). Among them there is U4 subtype, in which the anthropogenic cover dominates within all four search radii $(0.5 \mathrm{~km}-4 \mathrm{~km})$. It includes 6 of the biggest Polish cities in terms of population, with over 500 thousand of residents (e.g. Warsaw, Cracow, Poznań) and 12 smaller cities with a varied area located in agglomeration: Silesian (e.g., Bytom, Chrzanów, Zabrze) and Warsaw (e.g., Piastów, Prószków, Ząbki). Smaller cities in this subtype are areas affected by the impact of the anthropogenic landscape of the neighboring bigger cities.

Distinguished was the (U/a) subtype in the urbanized type (U), which is dominated by the agricultural landscape when a larger search radius are used. Depending on the number of search radii, in this subtype three classes were distinguished: $\mathrm{U} 3 / \mathrm{a} 1, \mathrm{U} 2 / \mathrm{a} 2$ and $\mathrm{U} 1 / \mathrm{a} 3$. In total, there are 101 cities in this subtype, with five having more than 100 thousand residents (e.g. Lublin - U3a1, Legnica U2/a2, Częstochowa - U1/a3).
The largest group in this subtype consists of 40 cities below $10 \mathrm{~km}^{2}$ (e.g.: Płoty - U2/a2, Kruszwica - U1/a3).

Another subtype (Uf) consists of cities dominated by the forest landscape when increasing the search radius. These are usually small cities located close to large forest complexes. Examples of cities belonging to this subtype are Kartuzy (U1/f3) and Mirosławiec (U2/f2).

A significant number of cities (76) was classified to an Um subtype. This group includes large cities in terms of population and surface area, where administrative boundaries outside urbanized areas are more diversified in terms of land use (e.g., Bydgoszcz, Gdańsk - U3 m1, Szczecin, Kielce - U2 m2, Olsztyn - U1 m3), as well as 63 cities of less than $50 \mathrm{~km}^{2}$ (Słupsk - U3 m1, Ełk - U2 m2, Brzesko U1 m3). Examples of cities belonging to selected types are presented in Fig. 8.

Selected groups of cities, including landscape background, can be helpful in shaping their spatial policy in relation to green areas because they include both the existing structure of urban greening and land cover outside the city borders. Consideration of four different search radii allows for assessment of a wider spatial spectrum of interactions 

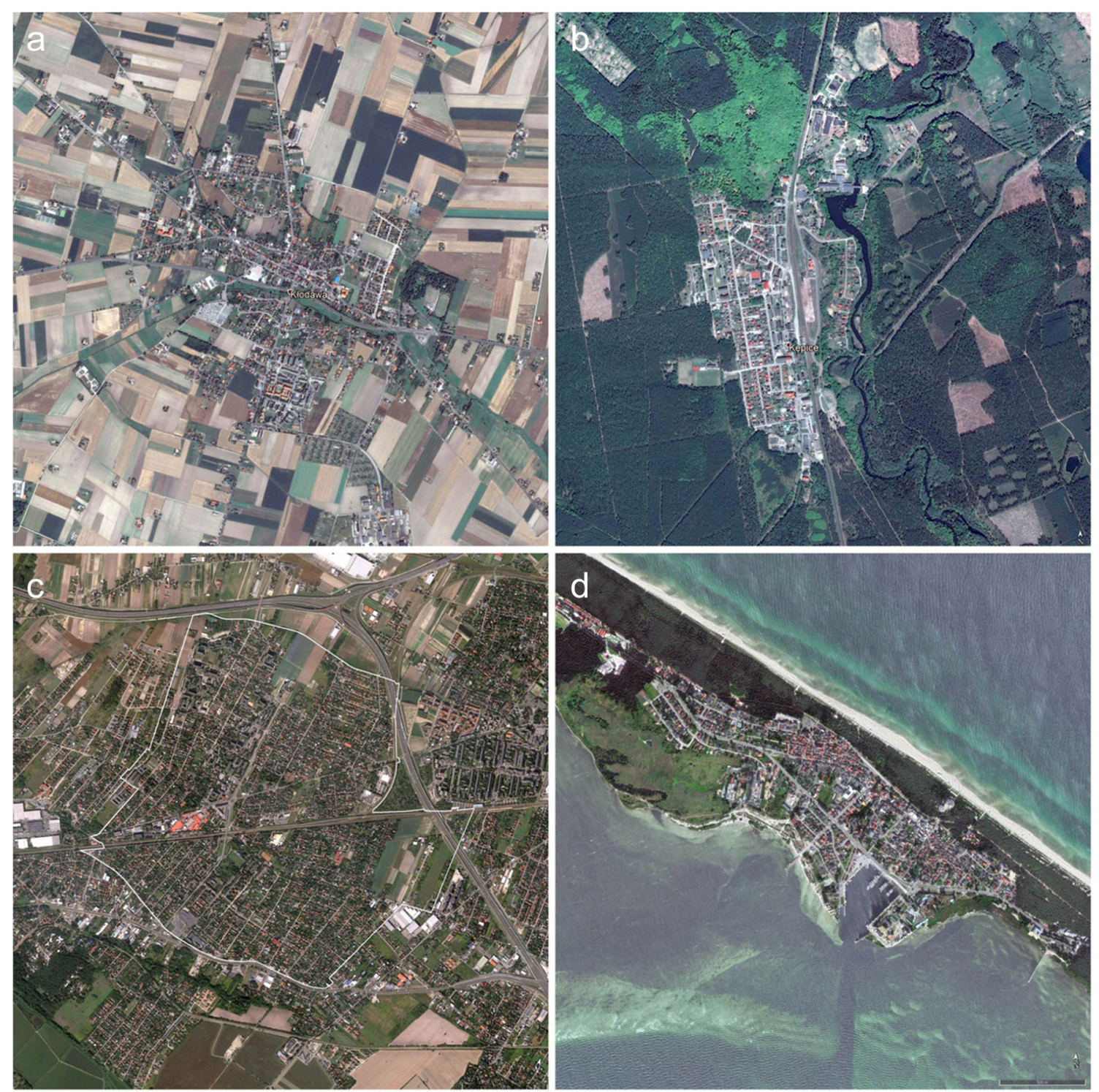

Fig. 8 An example of locating cities within the diversified landscape background. a Kłodawa (A4), b Kępice (F4), c Piastów (U4), d Jastarnia (W4). Source: Google Earth

between the land cover of a city and its surroundings. This is particularly important when implementing objectives of the policy of sustainable development of urban areas, in relation to creating greenery system connected with neighboring areas of cities.

Taking into account the formation of urban greenery, particular attention should be given to the type of urbanized cities (U), especially to relatively few cities in class U4 (18 cities), in which $25 \%$ of the Polish urban population lives. In addition to large cities, which are characterized by high levels of urbanization, lowering the quality of life of residents may concern relatively numerous group of smaller cities with a dense urban area, which with a larger search radius are located within the agricultural landscape (U3/a1, U2/a2, U1/a3) or regardless of the radius, belong to the (A4) type. These cities are heated primarily by coal, which causes severe air pollution from low emission (Kucęba and Kulej-Dudek 2016; Bell et al. 2006). Also, the chemical agents coming from agricultural areas have an impact on the quality of life. Altogether, in those four distinct groups resides more than $63 \%$ of the population.

Much better conditions are in the cities surrounded by forests, including cities of $\mathrm{F}$ type and $\mathrm{U} / \mathrm{f}, \mathrm{A} / \mathrm{f}$ and $\mathrm{M} / \mathrm{f}$ subtypes, due to their location in the landscape. Altogether, in this type and three subtypes lives 14\% of the urban population. With the exception of Silesian cities, most of them (especially of the F type) are cities of touristic and recreational character. Examples of Polish cities according to the adopted classification are presented in Table 2. 
Table 2 Examples of classification of selected Polish cities including their surface (cities size)

\begin{tabular}{|c|c|c|c|}
\hline Type & Cities size $\left[\mathrm{km}^{2}\right]$ & $\begin{array}{l}\text { The number of cities } \\
\text { in the selected type }\end{array}$ & Name of the cities including class symbol \\
\hline \multirow[t]{5}{*}{$\mathrm{U}$} & $>100$ & 16 & Warsaw (U4), Cracov (U4), Łódź (U4), Gliwice (U1/a3) \\
\hline & $50-100$ & 10 & $\begin{array}{l}\text { Sosnowiec (U4), Ruda Śląska (U4), Tychy (U2/m2), } \\
\text { Grudziądz (U1/a3) }\end{array}$ \\
\hline & $20-50$ & 53 & $\begin{array}{l}\text { Chorzów (U4), Siedlce (U3/a1), Tczew (U2/a2), } \\
\text { Żary (U1/f3). }\end{array}$ \\
\hline & $10-20$ & 66 & $\begin{array}{l}\text { Piaseczno (U4), Świętochłowice (U4), Wieliczka U3/a1, } \\
\text { Łask (U2/a2). }\end{array}$ \\
\hline & $<10$ & 58 & $\begin{array}{l}\text { Piastów (U4), Płoty (U2/a2), Mirosławiec (U2/f2), } \\
\text { Żnin (U1/a3). }\end{array}$ \\
\hline \multirow[t]{5}{*}{ A } & $>100$ & 3 & $\begin{array}{l}\text { Rzeszów (A4), Dąbrowa Górnicza (A2/m2), Jelenia } \\
\text { Góra (A3/m1) }\end{array}$ \\
\hline & $50-100$ & 20 & $\begin{array}{l}\text { Gorzów (A4), Kalisz (A4), Opole (A3/m1), } \\
\quad \text { Pieszyce (A1/f3) }\end{array}$ \\
\hline & $20-50$ & 112 & $\begin{array}{l}\text { Łomża (A4), Jasło (A4), Boguszów-Gorce (A2/f2), } \\
\text { Wałcz (A2/m2) }\end{array}$ \\
\hline & $10-20$ & 182 & $\begin{array}{l}\text { Koło (A4), Łańcut (A4), Lesko (A2/f2), } \\
\text { Kościerzyna (A2/m2) }\end{array}$ \\
\hline & $<10$ & 253 & $\begin{array}{l}\text { Łęczyca (A4), Choszczno (A4), Sejny (A4), } \\
\text { Supraśl (A2/f2) }\end{array}$ \\
\hline \multirow[t]{5}{*}{$\mathrm{F}$} & $>100$ & 7 & $\begin{array}{l}\text { Piła (F4), Wisła (F4), Katowice (F3/u1), } \\
\text { Jaworzno (F2/m2) }\end{array}$ \\
\hline & $50-100$ & 26 & $\begin{array}{l}\text { Augustów (F4), Zakopane (F4), Elblag (F3/m1), } \\
\text { Orzesze (F3/m1) }\end{array}$ \\
\hline & $20-50$ & 45 & $\begin{array}{l}\text { Żagań (F4), Wejherowo (F4), Hel (F2/w2), } \\
\text { Chrzanów (F2/m2) }\end{array}$ \\
\hline & $10-20$ & 35 & $\begin{array}{l}\text { Pionki (F4), Rzepin (F4), Biały Bór (F2/a2), } \\
\text { Łeba (F2/w2) }\end{array}$ \\
\hline & $<10$ & 18 & $\begin{array}{l}\text { Bardo (F4), Tuczno (F4), Ulanów (F3/a1), } \\
\text { Iwonicz Zdrój (F3/m1) }\end{array}$ \\
\hline \multirow[t]{5}{*}{$\mathrm{W}$} & $>100$ & 2 & Świnoujście (W4), Krynica Morska (W4). \\
\hline & $50-100$ & - & - \\
\hline & $20-50$ & 2 & Nowe Warpno (W4), Otmuchów (W2/a2) \\
\hline & $10-20$ & 3 & Wolin (W3/a1), Myślibórz (W2/a2), Sława (W2/m2) \\
\hline & $<10$ & 5 & $\begin{array}{l}\text { Jastarnia (W4), Dziwnów (W4), Moryń (W2/a2), } \\
\text { Ińsko (W1/m3) }\end{array}$ \\
\hline
\end{tabular}

\section{Conclusion}

The method of raster data generalization presented in this work allows for determining the location of cities in relation to land cover forms, as well as to divide them. This facilitates the assessment of the potential impact of land cover on the quality of life of the residents on a national scale. It takes into account the structure of land cover within the city as well as areas outside its boundaries.

The method was used, among others, when classifying all of 928 Polish cities in the administrative boundaries, including five forms of dominant landscape and four search radii. The type of city was determined by the dominant landscape within the administrative boundaries, calculated with the smallest search radius. Presented division allowed for selection of a group of cities in case of which particular attention should be paid to the way of shaping green urban areas in the context of their inhabitants' life quality. These groups include cities of the urbanized type (U), especially relatively small cities in U4 class, which are inhabited by $25 \%$ of Poland's population. Declining of the residents' life quality may concern also a large group of smaller cities in terms of area with densely built-up cities situated in agricultural or urbanized agricultural landscapes where there is a likelihood of harmful impact of the industry, residential energy, and air pollution from farming. Altogether, over $63 \%$ of the urban population lives in groups A4, U1/a3, U2/a2, U3/a1. Potentially the best conditions, due to the location in the landscape, have cities surrounded by 
forests, which are inhabited by $14 \%$ of the urban population. With the exception of Silesian cities, most of them are of touristic and recreational character.

Open Access This article is distributed under the terms of the Creative Commons Attribution 4.0 International License (http:// creativecommons.org/licenses/by/4.0/), which permits unrestricted use, distribution, and reproduction in any medium, provided you give appropriate credit to the original author(s) and the source, provide a link to the Creative Commons license, and indicate if changes were made.

\section{References}

Ahern J, Cilliers S, Niemelä J (2014) The concept of ecosystem services in adaptive urban planning and design: a framework for supporting innovation. Landsc Urban Plan 125:254-259

Antrop M (2004) Landscape change and the urbanization process in Europe. Landsc Urban Plan 67:9-26

Antrop M, Van Eetvelde V (2000) Holistic aspects of suburban landscapes: visual image interpretation and landscape metrics. Landsc Urban Plan 50:43-58

Arnberger A (2006) Recreation use of urban forests: an inter-area comparison. Urban For Urban Green 4(3-4):135-144

Asmann WAH, Sutton MA, Schjøring JK (1998) Ammonia: emission, atmospheric transport and deposition. New Phytol 139:27-48

Bagan H, Yamagata Y (2012) Landsat analysis of urban growth: how Tokyo became the world's largest megacity during the last 40 years. Remote Sens Environ 127:210-222

Balarasa CA, Gaglia AG, Georgopoulou E, Mirasgedis S, Sarafidis Y, Lalas DP (2007) European residential buildings and empirical assessment of the Hellenic building stock, energy consumption, emissions and potential energy savings. Build Environ 42(3):1298-1314

Balrama S, Dragicević S (2005) Attitudes toward urban green spaces: integrating questionnaire survey and collaborative GIS techniques to improve attitude measurements. Landsc Urban Plan 71:147-162

Basten L (2011) Aesthetics and design: perceptions in the postmodern periphery. In: Schmid, Heiko; Sahr, Wolf-Dietrich \& Urry, John (Hg.): cities and fascination. Beyond the surplus of meaning. (rematerialising cultural geography). Ashgate, Farnham, pp 75-91

Beelen R (2014) Effects of long-term exposure to air pollution on naturalcause mortality: an analysis of 22 European cohorts within the multicentre ESCAPE project. Lancet 383:785-795

Bell ML, Davis DL, Gouveia N, Borja-Aburto VH, Cifuentese LA (2006) The avoidable health effects of air pollution in three Latin American cities: Santiago, São Paulo, and Mexico City. Environ Res 100:431-440

Benedict MA, McMahon ET (2002) Green infrastructure: smart conservation for the $21^{\text {st }}$ century. Renew Resour J 20:12-17

Bjerke T, Østdahla T, Thrane C, Strumse E (2006) Vegetation density of urban parks and perceived appropriateness for recreation. Urban For Urban Green 5:35-44

Bruszewska K (2013) Tereny rolne w polskich miastach jako potencjał do kształtowania zielonej infrastruktury (Agriculture areas within Polish cities as potential to shape green infrastructure). Probl Landsc Ecolog 34:15-22 (in Polish with English summary)

Bryant MM (2006) Urban landscape conservation and the role of ecological greenways at local and metropolitan scales. Landsc Urban Plan 76:23-44

Collinge SK (1996) Ecological consequences of habitat fragmentation: implications for landscape architecture and planing. Landsc Urban Plan 36:59-77
Collinge SK (1998) Spatial arrangement of habitat patches and corridors: clues from ecological field experiments. Landsc Urban Plan 42: $157-168$

Cook EA (2002) Landscape structure indices for assessing urban ecological networks. Landsc Urban Plan 58:269-280

Drapella-Hermansdorfer A (2005) Zieleń-woda-recykling przestrzeni. Wybrane aspekty przyrodniczej rewitalizacji miast (Greenery-water-space recycling: selected aspects of natural revitalization of natural revitalization of cities). Teka Kom Arch Urb Stud Krajobr - OL PAN:35-43 (in Polish with English summary)

Escobedo FJ, Kroeger T, Wagner JE (2011) Urban forests and pollution mitigation: analyzing ecosystem services and disservices. Environ Pollut 159(8-9):2078-2087

Feranec J, Suri M, Otahel J, Cebecauer T, Kolar J, Soukup T, Zdenkova D, Waszmuth J, Vajdea V, Vijdea A, Nitica C (2000) Inventory of major landscape changes in the Czech Republic, Hungary, Romania and Slovak Republic. Int J Appl Earth Obs Geoinf 2:129-139

Feranec J, Hazeu G, Christensen S, Jaffrain G (2007) Corine land cover change detection in Europe (case studies of the Netherlands and Slovakia). Land Use Policy 24:234-247

GUS (2016) Statistical yearbook of the republic of Poland. Year LXXVI. Central Statistical Office, Warsaw

Hidding MC, Teunissen ATJ (2002) Beyond fragmentation: new concepts for urban-rural development. Landsc Urban Plan 58:297-308

Hobbs R (1997) Future landscapes and the future of landscape ecology. Landsc Urban Plan 37:1-9

Hościło A, Tomaszewska M (2014) CORINE land cover 2012-4th CLC inventory completed in Poland. Geoinformation Issues 6:49-58

Hulicka A (2015) Miasto zielone - miasto zrównoważone (Green cities - sustainability cities). Prace Geograficzne 141:73-85 (in Polish with English summary). https://doi.org/10.4467/ 20833113PG.15.010.4062

Kong F, Yin H, Nakagoshi N (2007) Using GIS and landscape metrics in the hedonic price modeling of the amenity value of urban green space: a case study in Jinan City, China. Landsc Urban Plan 79: $240-252$

Kucęba R, Kulej-Dudek E (2016) Zarządzanie niską emisją społecznościowa platforma transferu wiedzy (Low emission management - social knowledge transfer platform). Zeszyty Naukowe Politechniki Śląskiej 93:309-321 (in Polish with English summary)

Kuo FE (2003) Social aspects of urban forestry: the role of arboriculture in a healthy social ecology. J Arboric 29:148-155

Lelieveld J, Evans JS, Fnais M, Giannadaki D, Pozzer A (2015) The contribution of outdoor air pollution sources to premature mortality on a global scale. Nature 525:367-371

Li F, Wanga R, Paulussen J, Liu X (2005) Comprehensive concept planning of urban greening based on ecological principles: a case study in Beijing, China. Landsc Urban Plan 72:325-336

Matsuoka RH, Kaplan R (2008) People needs in the urban landscape: analysis of landscape and urban planning contributions. Landsc Urban Plan 84:7-19

Mierzejewska L (2015) Zrównoważony rozwój miasta - wybrane sposoby pojmowania, koncepcje i modele (Sustainable development of a city: selected theoretical frameworks, concepts and models). Probl Cit Develop 3:5-1 (in Polish with English summary)

Mierzejewska L (2015a) Miasto zwarte, rozproszone, zrównoważone (A compact, a dispersed, and a sustainable city). Studia Miejskie 19:9 22 (in Polish with English summary)

Miller JR, Hobbs RJ (2002) Conservation where people live and work. Conserv Biol 16(2):330-337

Myga-Piątek U (2010) Przemiany krajobrazów kulturowych w świetle idei zrównoważonego rozwoju (Transformation of cultural landscapes in the light of the idea of sustainable development). Probl Sustain Develop 5:95-108 (in Polish with English summary)

Naess P (2001) Urban planning and sustainable development. Eur Plan Stud 9:503-524 
Nowak JB, Neuman JA, Bahreini R, Brock CA, Middlebrook AM, Wollny AG, Holloway JS, Peischl J, Ryerson TB, Fehsenfeld FC (2010) Airborne observations of ammonia and ammonium nitrate formation over Houston, Texas. J Geophys Res 115:222-304

Opdam P, Steingrover E, van Rooij S (2006) Ecological networks: a spatial concept for multi-actor planning of sustainable landscapes. Landsc Urban Plan 75:322-332

Pieńkowski P, Podlasiński M (2017) Propozycja metody wyznaczania tła krajobrazowego w oparciu o wskaźnik dominacji form pokrycia terenu (Proposal of a method for determination background landscape based ond land cover domination index). Dissertations of Cultural Landscape Commission 35:9-18 (in Polish with English summary)

Pope CA, Dockery DW (2006) Health effects of fine particulate air pollution: lines that connect. J Air Waste Manage Assoc 56:709-742

Runge A (2012) Metodologiczne problemy badania miast średnich w Polsce (Methodological problems associated with research on midsize towns in Poland). Prace Geograficzne 129:83-101 (in Polish with English summary). https://doi.org/10.4467/20833113PG.12. 015.0523

Solon J, Chmielewski TJ, Myga-Piątek U, Kistowski M (2015) Identyfikacja i ocena krajobrazów Polski - etapy i metody postępowania w toku audytu krajobrazowego w województwach (Identification and assessment of Polish landscapes - stages and methods of action within the landscape audit in the administrative regions). Probl Landsc Ecolog 50:55-76 (in Polish with English summary)
Stigell E, Schantz P (2015) Active commuting behaviors in a Nordic metropolitan setting in relation to modality, gender, and health recommendations. Int J Environ Res Public Health 12:15626-15648

Sutton MA, Asman WAH, Ellermann T, Van Jaarsveld JA, Acker K, Aneja V, Duyzer J, Horvath L, Paramonov S, Mitosinkova M, Tang YS, Chermann B, Gauger T, Bartniki J, Neftel A, Erisman JW (2003) Establishing the link between ammonia emission control and measurements of reduced nitrogen concentrations and deposition. Environ Monit Assess 82:149-185

Szymańska D (2007) Urbanizacja na świecie (Urbanization in the world). PWN, Warsaw (in Polish)

Troy AR, Grove JM, O’Neil-Dunne PMJ, Pickett STA, Cadenasso ML (2007) Predicting opportunities for greening and patterns of vegetation on private urban lands. Environ Manag 40:394-412

Vuilleumier S, Prelaz-Droux R (2002) Map of ecological networks for landscape planning. Landsc Urban Plan 58:157-170

Wolch JR, Byrne J, Newell JP (2014) Urban green space, public health, and environmental justice: the challenge of making cities "just green enough". Landsc Urban Plan 125:234-244

Xiao J, Shen Y, Ge J, Tateishia R, Ch T, Liang Y, Huang Z (2006) Evaluating urban expansion and land use change in Shijiazhuang, China, by using GIS and remote sensing. Landsc Urban Plan 75:69-80

Żarska B (2005) Ochrona krajobrazu (Landscape protection). SGGW, Warsaw (in Polish)

Zhang L, Wu J, Zhen Y, Shu J (2004) A GIS-based gradient analysis of urban landscape pattern of Shanghai metropolitan area, China. Landsc Urban Plan 69(1):1-16 